\title{
Yunus Emre’nin Dilinde Karşıt Anlamlı Çiftler Üzerine Söz Dizimsel
}

\section{Bir Analiz}

\author{
A Syntaxal Analysis on Antonym Pairs in the Language of Yunus Emre
}

\author{
Dr. Öğr. Üyesi Erol KUYMA (iD)
}

\begin{abstract}
$\ddot{\mathbf{O} z}$
Dilsel anlam ilişkileri arasında yer alan karşıt anlamlılık, günlük konuşma dilinden edebi söylemlere uzanan bir kullanım alanına ve sıklığına sahiptir. Duygu ve düşüncelerin aktarımında etkili bir söyleyiş tarzı oluşturmak ve anlatımı daha dikkat çekici kılmak için karşıt anlamlı sözlere başvurulur. Karşıt anlamlılık (antonymy), aralarında anlam yönüyle zıtlık bulunan sözcükler arasında gerçekleşir. Karşıt anlamlı çiftler ad, zarf ve sıfat türünde sözcüklerden oluşabileceği gibi fiillerden de meydana gelebilir. Genelde karşıt anlamlılıkla ilgili çalışmaların anlamsal/kavramsal bir çerçevede yapıldığı görülmektedir. Aslında söz dizimsel yapılar da karşıt anlamlı çiftlerin bağlam içi kullanımlarını belirleyen/etkileyen bir özelliğe sahiptirler. Bu çalışmada, Yunus Emre Divanında yer alan karşıt anlamlı çiftlerin kullanım birliktelikleri üzerine söz dizimsel bir inceleme yapılmıştır. Hem Eski Anadolu Türkçesi döneminin hem de tasavvufi şiir geleneğinin en önemli isimlerinden olan Yunus Emre, şiirlerinde tasavvufi düşüncenin halkın anlayacağı bir dile ve milli bir kimliğe ulaşmasında önemli bir rol üstlenmiştir. Yapılan incelemede, karşıt anlamlı çiftlerin önemli bir kısmının X v̈̈ Y, hem X hem Y, ne X ne Y, ger X ger Y, eger X eger Y, X ile / \{+(y)IlA\} Y, gâh X gâhY, kimi X kimi Y, kimin X kimin Y, biri X biri $Y$ şeklinde bağlaçların etkin olduğu yapılarda yer aldığı görülmektedir. Söz konusu söz dizimsel yapılar, karşıt anlamlılı̆̆ daha da belirginleştiren bir etkiye sahiptirler.
\end{abstract}

Anahtar Kelimeler: Karşıt anlamlılık, Yunus Emre, Söz dizimsel yapı

Makale Türü: Araştırma

\begin{abstract}
Antonym, which is among linguistic meaning relations, has a usage area and frequency ranging from colloquial language to literary language. Opposite words are used in order to create an effective style of expression in the transfer of feelings and thoughts and to make the expression more remarkable. Antonymy, occur between words that are opposite semantically. Antonymy pairs, can occur in words such as nouns, adverbs and adjectives, as well as verbs. In general, it is seen that studies on antonymy are carried out in a semantic/conceptual framework. In fact, syntactic structures have a feature that determines/affects the in-context use of antonyms. In this study, a syntactic analysis was made on the usage pairs of antonyms in Yunus Emre's Divan. Yunus Emre, one of the most important names of both the Old Anatolian Turkish period and the sufic poetry tradition, an important role in reaching a national identity that the people could understand. In the examination, it is seen that a significant part of the pairs of antonyms are located in the structures in which $X v \ddot{v} Y$, hem $X$ hem $Y$, ne $X$ ne $Y$, ger $X$ ger $Y$, eger $X$ eger Y, X ile / $\{+(y) I l A\} Y$, gâh X gâhY, kimi X kimi Y, kimin X kimin Y, biri X biri $Y$ shaped conjunctions are effective. These syntactic structures make the antonymy even more pronounced.
\end{abstract}

Keywords: Antonymy, Yunus Emre, Syntactic structure

Paper Type: Research

\footnotetext{
${ }^{1}$ Hitit Üniversitesi, Fen-Edebiyat Fakültesi, Türk Dili ve Edebiyatı Bölümü, erolkuyma@ hitit.edu.tr

Atıf için (to cite): Kuyma, E. (2021). Yunus Emre'nin dilinde karşıt anlamlı çiftler üzerine söz dizimsel bir analiz. Afyon Kocatepe Üniversitesi Sosyal Bilimler Dergisi, 23(Yunus Emre ve Türkçe Özel Sayıs1), 69-82.
} 


\section{Giriş}

Dil, ögeleri arasında çeşitli ilişkiler (dizisel/dizimsel) bulunan bir yapı, bir dizgedir (Kıran ve Eziler Kıran, 2002, s. 239). Anlatımın/iletişimin gerçekleşebilmesi için dili oluşturan unsurlar arasında anlamsal, söz dizimsel ya da yapısal bir ilişkinin kurulması gerekir. Bu ilişkiler, art zamanlı ve eş zamanlı olarak bazı değişimlere uğrayabilir veya sözcükler arasında hem anlamsal hem de söz dizimsel yeni ilişkiler kurulabilir. Söz konusu değişim ve ilişkilerde bağlam içi kullanımlar kadar sözcüklerin yer aldığı söz dizimsel yapılar da rol oynar. Göstergeler, hemen her zaman içinde geçtikleri tamlamalar, tümceler ve sözcelerde, öteki sözcüklerle oluşturdukları bütünle kesinlik kazanır, belli bir kavramı eksiksiz yansitır (Aksan, 2016, s. 94). Yapı ve anlam arasında belirli bir ilişki bulunmaktadır. Bazı unsurlar, bu ilişkiyi belirginleştiren bir rol üstlenirler. "Ne iyi ne kötü", "kimi ăglar kimi güler" örneklerinde de görüldüğü gibi bağlaçların "iyi:kötü, ăgla-:gül-" sözcükleri arasındaki karşıt anlamlılığı daha da vurgulu hale getiren bir işlevi söz konusudur.

Karşıt anlamlı sözcüklerin birlikte kullanımında görülen söz dizimsel yapılar, Türk dilinin tarihsel dönemlerinde de gözlemlenmektedir. Çalışmamızda, Yunus Emre Divanı'nda geçen karşıt anlamlı sözcükler tespit edilerek bu sözcüklerin söz dizimsel yapı içerisindeki kullanımları ele alınmıştır.

Yunus Emre, 13. yüzyılın sonları ile 14. yüzyılın başlarında yaşamış, Eski Anadolu Türkçesi ile şiirler söylemiş büyük bir mutasavvıftır. Halk diliyle ortaya koyduğu son derece sade, anlaşılır üslubu, hem halk tarafından hem de sonraki mutasavvıflar tarafindan kabul görmüştür.

13. yüzyılda, mutasavvıf şairler, vahdet-i vücut felsefesini ve düşüncesini halka benimsetmeye çalışmışlar, bu düşünce tarzına dil, şekil ve vezin bakımından milli bir nitelik kazandırmaya gayret etmişlerdir. Yunus Emre, bu yabancı felsefi unsuru milli unsurla birleştirerek zevk bakımından Acem tasavvufi eserlerinden tamamen farklı, bir Türk tasavvuf edebiyatının oluşmasına vesile olmuştur (Köprülü, 2020, s. 358-359). Tezcan, Yunus'un şiirlerinde eskicil (arkaik) görünen ancak 14. Yüzyıl Türkçesinde kullanımda olan, herkesin bildiği birçok sözcük bulunduğunun altını çizerek bu kelimelerin hemen hepsinin yeni yazı dilinde 16. yüzyıla kadar kullanıldığını belirtir. Bu sözcüklerin bir kısmı sonradan ya tamamıyla unutulmuş ya da dilde kullanılmayıp sadece ağızlarda yaşamaya devam etmiştir. Çoğu Türkçe kökenli olan bu sözcüklerin arasında Türkçeye çok önceden diğer dillerden gelip yerleşmiş sözcükler de bulunmaktadır (Tezcan, 2012, s. 114-115). 13-14. yüzyıl söz varlığının günümüze ulaşmasında büyük bir rol üstlenen Yunus, şiirlerinde tasavvufi düşüncenin aktarımında karşıt anlamlı sözcükleri de ustalıkla kullanmıştır.

Zıtlıklar, anlatımda öne çıkarılmak istenen duygu ve düşüncenin vurgulanmasında etkili bir söyleyiş sağlarlar. Karaağaç (2013, s. 364), metin kurgulamada karşı tezler oluş̧urmak için kullanılan karşıt anlamlıların sayesinde düşüncelerin daha açık ve anlaşı1ır şekilde ifade edildiğinin altını çizer. Eş anlamlılık, çok anlamlılık, alt anlamlılık, üst anlamlılık gibi dilsel anlam ilişkilerinden biri olan karşıt anlamlılık, duygu ve düşüncelerin aktarımında etkili bir üslup özelliği taşır.

\section{Karşıt Anlamlılık}

Genelde karşıt anlamlılık, "anlamları birbirine karşıt/aykırı olan sözcüklerin arasındaki ilişki, karşıt olma durumu/özelliği (Hatiboğlu, 1978, s. 80; İmer, Kocaman ve Özsoy, 2011, s. 170; Kıran ve Eziler Kıran, 2002, s. 248; Korkmaz, 2007, s. 143; Vardar, 2002, s. 130) gibi benzer ifadelerle tanımlanmaktadır. Karaağaç (2013, s. 363), her bilginin karşıt bir bilgiyle doğduğunun altını çizerek karşıt anlamlı sözlerin birbirlerinin ses, yapı ve kullanım alanlarını doğrudan etkilediğini bildirir. 
Karşıt anlamlılıkta, sözcüklerin ortak bir anlam ekseninde hareket etmesi esas olarak kabul edilmektedir. Diğer dilsel anlam bağlantılarında olduğu gibi bağlam içi kullanımlar, sözcük çiftleri arasındaki karşıt anlamlılığın oluşmasında belirleyici rol oynar. "Açık:kapalı" karşıt çiftinin söz dizimsel düzlemdeki görünümü üzerinden örnek verilirse;

(a) Hava bugün ne kapalı ne açık.

(b) Kapalı ortamlar, virüse bağlı enfeksiyonlara karşı insanları açık hale getiriyor.

(a)Anlamsal bileşenlerle derin yapıda beliren karşıtlık, bulutlu:bulutsuz/ güneşli:güneşsiz / aydınlık:karanlık şeklindedir. Kapalı:açık karşı çiftleri arasında kavramsal düzeydeki karşıtlık ne...ne bağlacı ile kurulan öbekleşme ile yapısal bir görünüm de kazanmaktadır.

(b)“Kapalı” sözcüğü ortam sözcüğünün sıfatı görevinde havası, kısıtlı anlamında; "açık" sözcüğü ise "hal" sözcüğü öncesinde yine sıfat görevi ile savunmasız anlamında kullanılmıştır. "havasız, kısıtlı ile savunmasız sözcükleri arasında herhangi bir karşıt anlamlılıktan söz edilemez.

Karşıt anlamlılığın tanımı ile ilgili belirgin farklılıklar bulunmasa da sınıflandırma ve adlandırmada farklılıklar görülebilmektedir. Bunlardan bazıları;

Cruse (2000, s. 167-174), Opposites (karşıtlıklar/zıtlıklar) başlığ1 altında yaptığ1 sınıflandırmada, karşıt anlamlılığı (antonymy) ayrı bir madde olarak ele alır: içeri:dışarı.

1.Complementaries (tamamlayıcılar/bütünleyiciler):ölü:canll, doğru:yanlış,

2.Antonymy (karşıt anlamlılık): a.Polar antonyms (kutupsal karşıt anlamlılar): uzun:klsa, hızll:yavaş, büyük:kü̧̈ük. Bu bölüm altındakilerin aynı zamanda derecelenebilir olduğunu belirtir. b.Equipollent antonyms (eşdeğer karşıt anlamalılar): sicak:soğuk, acı:tatll, mutluu:üzgün. c.Overlapping antonyms (örtüşen karşıt anlamalılar): iyi:kötü, nazik:kaba, akıllı:aptal

3. Reversives (ters yönlü olanlar): Bu gruptakiler yön gösteren karştllklardır, yukarı:aşağı, ileri:geri, üst:alt.

4. Converses (karşıttters olanlar): Bu gruptakiler yön gösteren karştlıklardır, üst:alt, önce:sonra, ödünç vermek:ödünç almak,

5. Markedness (işaretli/belirtili olanlar): Dağllımsal, semantik ve morfolojik işaretliler, olmak üzere üç çeşittir.

6. Polarity (kutupsallik): Mantıksal, morfolojik, özel ve tutum belirten olmak üzere dört çeşittir.

Palmer (2001, s. 104-197), zıt anlamlılık başlı̆ğ altında karşı1t anlamlılı̆̆1, 1. Dercelenebilir (gradability), 2. Tamamlayıcı (complementarity), 3. Ilişskisel (relational) zıtlar olarak siniflandirır.

Kıran ve Eziler Kıran (2002, s. 248), beş başl1kta ele alır: 1. Ara kavram içermeyenler: ölüm:yaşam, kadın:erkek, 2. Ara evreler içerenler: sıcak:ılık:serin:soğuk, 3. Bütünleyici:evli bekar,4. Karşıllk içeren: almak:satmak, 5. Sadece karşıtllk ifade eden: büyük:küçük.

Kerimoğlu (2014, s. 213-214), 1.Bütünleyici (complemantary) karşıtllk, 2.Dereceli (gradable) karşıtlık, 3.Bağlamsal (relationall karşıtllı)) şeklinde üç başlığa yer verir.

Yapılan çalışmalarda karşıt anlamlılık, genelde kavramsal/anlamsal boyutta ele alınmaktadır. Oysa karşıtlık oluşturan unsurların bağlam içi hareket tarzı ve birliktelikleri, karşıt anlamlılığın oluşumunda söz dizimsel bir etkinin de olduğunu gösterir. Bu açıdan, karşıtlık 
konusunda yapılacak metin ya da söylem temelli çalışmalarda, söz dizimsel analiz ve sınıflandırmalar, özellikle yapı-anlam ilişkisini belirlemek açısından önem taşımaktadır.

Bu konuda yaptığı derlem tabanlı çalışmasıyla tanınan Jones (2002, s. 45-94), karşıtlıkları, birlikte kullanıldıkları söz dizimsel yapıları da esas alarak majör ve minör gruplar şeklinde farklı bir sınıflandırmaya tabi tutar. Onun sınıflandırması:

Majör grup: Ancillary Antonymy (bă̆ımllyardımcı karşıt anlamlılık) ve Coordinated Antonymy (eşgüdümlü karşıt anlamlılık);

Minor grup: Comparative Antonymy (klyaslı/karşılaștırmalı karşıt anlamlllık), Distinguished Antonymy (ayırt edici karşıt anlamlılık), Transitional Antonymy (geçişken karşıt anlamlılık), Negated Antonymy (olumsuzlanan karşıt anlamlılık), Extreme Antonymy (Uzak/uç karşıt anlamlılık), Idiomatic Antonymy (deyimsel karşıt anlamlılık) başlıklarından oluşur.

Akşehirli (2018, s. 43), Jones'un tasnifine de yer verdiği "Türkçede Bağımlı Karşıt Anlamlılık" adlı çalışmasında, Jones'un karşıt anlamlılık üzerine yaptığı çalışmanın alanyazında derlem tabanlı çalışmaların en önemlilerinden biri olmasının yanı sıra, bu anlam olgusunun söylemsel işlevleri açısından yeniden sınıflanması bakımından da önem taşıdığına dikkat çeker. Bir başka çalışmasında, karşıt anlamlılığı yapısal düzlemde ele alan Akşehirli (2014), başta olumsuzluk olmak üzere çeşitli dil bilgisel ve söz dizimsel yapılarla ve bağlaçlardan oluşan "yapısal karşıtlık tetikleyiciler"den söz eder.

\section{Yöntem}

Bu çalışmada, Yunus Emre'nin dilinde görülen karşıı anlamlı çiftlerin birlikte yer aldığ1 söz dizimsel yapılar tespit edilmeye çalışılmıştır. Bu amaçla Yunus Emre Divanı (Tatçı, 2008) taranmış ve 92 adet karşıt anlamlı çifte ulaşılmıştır. Tespit edilen karşıtlıklar, içinde yer aldıkları yapılara göre sınıflandırılmış, örneklerin geçtiği yerler, alıntıların sonunda şiir numarası/birim numarası şeklinde belirtilmiştir. Örnek: $\boldsymbol{O} \boldsymbol{d} \boldsymbol{u} \boldsymbol{s} \boldsymbol{u}$ vü toprag1 yili bile (379/2).

Çalışmamızda kuramsal olarak Jones'un (2002) karşı1 anlamlı çiftleri söz dizimsel niteliklere göre sınıflandırdığı yaklaşım esas alınmış, Divan'dan tespit edilen karşıt anlamlı çiftler, söz dizimsel olarak dört ana başlıkta kategorize edilmiştir. Bu kategorilerden ikisi Jones'un sinıflandırmasında da yer alan "eşgüdü̈mlü karşıt anlamlılık (coordinated antonymy)" ve “olumsuzlanan karşıt anlamlılı (negated antonymy)” örneklerinden oluşmakta, diğer iki kategori ise "ikilemeler şeklinde karşıt anlamlılık" ve tarafımızdan adlandırılan "seçenekli/nöbetleșe karşıt anlamıılık" başlığındaki örnekleri içermektedir.

\section{Yunus'un Dilinde Karşıt Anlamlı Çiftler ve Yer Aldıkları Söz Dizimsel Yapılar}

\subsection{Eşgüdümlü Karşıt Anlamlılık (Coordinated Antonymy)}

Karşıt anlamlı çiftlerin birlikte yer aldığ $X$ ve $Y, X$ veya/ya da $Y$, hem $X$ hem $Y$, ne $X$ ne $Y$, ister $X$ ister $Y$, ya $X$ ya $Y$, ne kadar/nasil $X$ ya da $Y$ gibi söz dizimsel yapılardır (Jones, 2002, s. 73-74). Bu yapıda çiftin her iki üyesini de içeren ya da her iki üyesini de anlamsal ya da göndergesel olarak dişlayan bir işlev söz konusudur (Akşehirli, 2018, s. 44).

Divan'dan seçilen karşıt anlamlı çiftlerin yapısal birliktelikleri, benzer işlevli bağlaç ya da sözcük tekrarları ile sağlanmıştır: $X u Y / X$ vü $Y$, hem $X$ hem $Y \ldots$, ne $X$ ne $Y$, ger $X$ ger $Y$ / eger X eger $Y$, gerek/gerekse, $X$ gerekse $Y, X$ ile / $\{+(y) I l A\} Y, X$ oldur $Y$ ol / oldur X oldur $Y / X$ ol $Y$ ol, ya $X$ ya $Y$

\subsection{1. $X$ и $Y / X$ vӥ $Y$}

od:su

Od $\boldsymbol{u} \boldsymbol{s u}$ vü toprag1 yili bile (379/2)

dost:düşmân 
Bilmez misin gayretsüze dost $\boldsymbol{u}$ düşmân gülesini (348/9)

yaz:kış

Benüm durur bu cümle iş hikmetile bu yaz u kış (77/1)

dün:gün

Yûnus imdi sen Hakk'a ir dün ü gün gönlün Hakk'a vir (24/5)

sûd(fayda):ziyân

Ârif midür ol anlamaya sûd u ziyânı (357/2)

küfr:îmân

Gerekse kâfir olam küfr ü îmândan fârig (126/4)

kıyam: rükû/secde

Nisbet degüldür ana hem secde vü rük $\mathbf{u}$ u klyâm (209/6)

yazug:müzd

Pes niçe ansun ol kişi yazug $\boldsymbol{u}$ müzd ass1-ziyân (259/3)

yir:gök / arş:ferş

Bu yir ü gök $\ddot{\boldsymbol{u}}$ arş $\boldsymbol{u}$ ferşs 1şk dadıyıla kâyımdur (32/3)

senlik:benlik

Cânile ârif olup senlik $\ddot{u}$ benlik terk idem (201/27)

ogul:kız

Bunda dahı virdün bize ogul $\boldsymbol{u} \boldsymbol{k} \boldsymbol{z} \boldsymbol{z}$ çift ü helâl (234/5)

hâs:âm

Ben seni sevdügümi işitsünler hâs $\boldsymbol{u}$ âm (202/1)

ag:kara

Kan yaş akıdur $\boldsymbol{a g} \boldsymbol{u}$ karadan (284/4)

zâhir:pinhân

O cân kim zâhir ü pinhân-1 '1şkdur (90/2)

dünyâ:âhiret

Bu dîn $\ddot{\boldsymbol{u}}$ diyânetde dünyâ vü âhiretde (116/2)

şark:garb

Şarka vü garba ser-te-ser yire göge toldum ahî (370/10)

ata:ana

Hoşnud ata vï anadan kullık kadrin bilen benem (194/2)

ulvi:süfli

Ulvî vï süflî cümleten oldur ger bana görine (14/5)

gice:gündüz

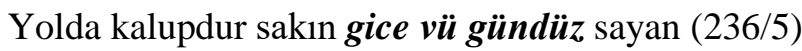

âşikâre:nihân 
Sen bilürsin âşikâre vï nihân (417/27)

3.1.2. hem $X$ hem $Y$...

pîr (yaşlı):cüvân (genç)

Nevbet irse yöñerür hem pîre hem cüvâne (313/8)

vir-:al-

Hem virürler hem alurlar ben bir ulu dîvân oldum (176/6)

derd:dermân

Kim sana ben sidk olam hem derd ü hem dermân olam (201/42)

bâtın:zâhir / evvel: âhir

Hem bâtınam hem zâhirem hem evvelem hem âhirem (211/8)

\subsection{3. ne $X$ ne $Y$}

şâd:gam

Bundan ulu 1ssı makâm $\boldsymbol{n} \boldsymbol{e}$ şâd vardur ne gam (331/5)

Leylâ:Mecnûn

Ne Leylâ idüm anda ne Mecnûn-1 ser-gerdân (260/5)

zeber (üst):zîr (alt)

Ne gök varıdı ne yir ne zeber vardı ne zîr (243/9)

puta hâça tap-:dîn ü imân tut-

Ne pûta-hâça taparam ne dîn ü imân tutaram (180/7)

yir:gök

Yûnus bak neredesin ne yirde ne gökdesin (151/9)

assı:ziyân

Ne assı var ne ziyân gelsün cânuna kıyan (416/5)

irte:gice

Başuma dikeler hece ne irte bilem ne gice (241/5)

yohsul:bay

Ne yohsul u ne baydasın ne köşk ü sarâylardasın (186/4)

deryâ:katre

Ne deryâdur ne katredür gör indi (411/1)

var:yok

Ne sermâyem ola ne var ne yokvam (203/7)

âkil:dîvâne

Ne âkilem ne dîvâne (404/2)

uslu:delï

Ne usluyam ne delüyem neye benzer işüm benüm (214/4)

ölü:diri 
Ne ölüsin ne diri hîç tenün yokdur senün (147/5)

\section{kul:sultân}

Hak'dan söyler bu dilüm ne kul ne sultân bana (12/3)

\section{tamu:uçmak}

Ne Tamu'da yir eyledüm

Ne Uçmak'da köşk bagladum (381/7)

esrük:ayık

Ne esrük ne humâr ne hod ayıkvam (203/4)

hayr:şer

Hicâb kalmadı ana ayruk ne hayr u ne şer (26/3)

\subsection{4. ger X ger Y / eger X eger $Y$}

erkek:dişi

Uzatdı bu halk işi ger erkek $\ddot{u}$ ger dişi $(115 / 2)$

\section{bay:yoksul}

Eger baydur eger yoksul ol eyler (95/9)

hayr:şer

Kim kime ne dirise eger hayr u eger şer (124/4)

\subsection{5. gerek/gerekse X gerekse $Y$}

müsülmân ol-: kâfir ol-

Gerek müsülmân olam bin y1l ibâdet k1lam

Gerekse kâfir olam küfr ü îmândan fârig (126/4)

uryân yüri-:libâs gey-

Gerekse uryân yüri gerekse geygil libâs (119/2)

\subsubsection{X ile / $\{+(y) I l A\} Y$}

od:su

Odıla su toprag u yil bünyâd k1lan Yezdân benem (211/6)

\section{Leylî:Mecnûn}

Leylî ile Mecnûn olup Ferhâd ile taşlar yonup (253/6)

\section{karga:bülbül}

Kargayıla bülbüli bir kafese koysalar (352/3)

\section{gice:gündüz}

Gice ile gündüzi gökde yidi yılduzı (133/4)

yir:gök

Yaradıldı yir ile gök Muhammed dostlııına (386/7)

câhil:ârifün

Câhil ile ârifün meseli şuna benzer (352/5) 


\section{dün:bugün}

Ezel-ebed sorarısan dün ile bugündür bana (7/8)

âşık:ma'şûk

Gül ü reyhânun kokusı âşıkıla ma'şûkadur (3/7)

uçmag:tamu

Uçmagıla Tamu'yı cümle vücûdda bulduk (133/3)

yalan:gerçek

Yalanıla gerçegi berâber tutmayalar (57/6)

\subsubsection{X oldur Y ol / oldur X oldur Y / X ol Y ol}

\section{viren:alan}

Viren oldur alan ol sormaz nedür ziyânı (395/4)

gelen:giden / görinen:gören

Her gelen oldur giden ol görinen oldur gören ol (14/5)

âhir:ebed

Oldur âhir oldur ebed hem dillerde Küfven ahad (63/5)

\section{öldüren:dirgüren}

Öldüren ol dirgüren ol Yûnus imdi Hakk'1la ol (112/7)

\subsection{8. ya X ya $\mathrm{Y}$}

\section{bugün:yarın}

Geldüm dünyâyı seyr itdüm ya bugün ya yarın gitdüm (204/5)

\section{kul:sultân}

Ya kul ya sultân dimeyem kalsun işidenler tana (7/3)

\subsection{Olumsuzlanan Karşıt Anlamlılık (Negated Antonymy)}

Karşıt anlamlı çiftten birinin karşıt anlamlılı̆̆ artırmak amaciyla diğerini reddeden/olumsuzlayan bir çerçevede kullanılmasıdır. X değil Y, X yerine $Y$, X'e karşı/karşın $Y$ şeklinde söz dizimsel bir özellik gösterir (Jones, 2002, s. 88). Akçataş, Türkiye Türkçesinde olumsuzlama edatı "değil" ile "nitelikte olumsuzlama, amaç-sonuçta olumsuzlama, bilgide olumsuzlama, mastarda olumsuzlama, tanımlamalarda olumsuzlama, sahiplikte olumsuzlama şeklinde kurulan altı tür karşı̂t anlamlı ilişsiden bahseder (Akçataş, 2011, s. 313-314). Divan'dan derlenen karşıt anlamlı sözcüklerin birlikte kullanıldığı sözdizimsel yapılarda "değil" edatının yanı sıra olumsuzluk eki $-m A$, ve "yok" sözcüğü de yer almaktadır: $\boldsymbol{X} \boldsymbol{d e g} \boldsymbol{u} \boldsymbol{l} \boldsymbol{Y} \boldsymbol{Y}\{\boldsymbol{D} \boldsymbol{D} \boldsymbol{r}\}$ / $X\{+D U r\} Y$ degül, X olma Y ol, X yok Y $\{+D A d u r\}$.

\subsubsection{X degül $Y\{+D U r\} / X\{+D U r\} Y$ degül}

\section{bâkî:fâni}

Bu dünye kahır evidür hem bâkî degül fânîüur (137/2)

\section{sag:sol}

Ol gerçege âşıklar küllî sagdur sol degül (163/7)

yalan:gerçek 
Yalan degül gerçekdür ben de gördüm tozını (407/5)

uslu:delü

Uslu degül delüdür yüce sarâylar yapan (380/3)

agu:bal

Agudur bal degül dünyâ murâdı (279/4)

\subsubsection{X olma Y ol}

diken:gül

Diken olma gül ol eren yolında (279/6)

\subsubsection{X yok $Y$ \{+DAdur\}}

\section{assı:ziyân}

Şol cân ki tapmadı Hakk'a assısı yok ziyândadur (54/5)

\subsection{Seçenekli/Nöbetleşe Karşıt Anlamlılık}

Bu başlık altında yer alan ve tarafımızdan adlandırılan karşı anlamlı söz dizimsel yapılar, Jones'un sınıflandırmasına birebir uygunluk göstermeyen, Türkçeye özgü farklı söz dizimsel yapılardan oluşmaktadır: Korkmaz, başlıcaları bazen ... bazen, bazı ... bazı, bir ... bir, biri ... öbürü, kah ... kah, kimi ...kimi şeklindeki tekrarlı bağlaçları nöbetleşme bağlaçları olarak adlandırır. Bu bağlaçların, cümledeki iki öge arasında, çeşitli yönlerden seçenekli bir bağlama işlevi gördügünü bildirir (Korkmaz, 2009, s. 1118-1121). Divan'dan derlenen karşıt anlamlı sözcüklerden bazıları gâh X gâh/geh Y, kimi X kimi Y / kimin X ... kimin Y, biri X biri $Y$ gibi nöbetleşme bağlaçları ile söz dizimsel bir yapıda yer alırken bazıları bir niçeleri $X$ bir niçeleri Y, bir niçemüz $X \ldots$... bir niçemüz $Y \ldots$, bir dem ... X ... bir ... Y ... şeklinde tekrar eden söz dizimsel yapılar içinde yer almışlardır.

\subsection{1. gâh X gâh/geh $Y$}

âzâd ol-:mahbûs ol- /zindândan çık-: zindân ol-

Gâh zindândan çıkam âzâd olam âbâd olam

Geh gine derbân olam mahbûs olam zindân olam (201/34)

mutî ol-:âsî ol-

Geh $\boldsymbol{m} \boldsymbol{u} \boldsymbol{t} \hat{\imath}^{\prime}$ olam Hudâ'nun emrine bin cân ile

Geh dönem 'âsî olam Mûsî olam 'İmrân olam (201/ 32)

duzah:cennet

Gâh duzahda yanam Firavn'1la Hâmân'1la

Gâh cennetde varam Gilmân'ila Ridvân olam (201/14)

gül-:agla-

Irmak gibi ben çaglaram gâh gülerem gâh aglaram (187/2)

in-:çık-

Gâh inem esfellere şeytânıla şerler düzem

Geh çıkam Arş üstine seyrân olam cevlân olam (201/9)

\subsection{2. bir niçeleri $X$ bir niçeleri $Y$ / bir niçemüz $X$... bir niçemüz $Y$...}

ışk düz-: ışk boz- 
Bir niçeleri ı̧ş düzer bir niçeleri ışk bozar (47/2)

\section{Leylî:Mecnûn}

Bir niçemüz Leylî old1 bir niçemüz Mecnûn old1 (118/5)

\subsection{3. kimi X kimi $Y / \operatorname{kimin} X \ldots$... kimin $Y$}

ulu:kiçi

Kimi ulu kimi kiçi key kuşagı berkler yatur (82/1)

yiğit:koca

Kimi yigit kimi koca kimi vezir kimi hoca (82/2)

kâfir:müselmân

Kimin kâfir idüp kimin müselmân

bay:yoksul

Kimi baydur kimi yoksul dime kim (95/9)

3.3.4. bir dem X bir dem Y, bir dem ... X ... bir dem ...Y ...

âsî:mutî

Bir dem 'âbid bir dem zâhid bir dem âsî bir dem mutî (278/4)

\section{Musa:Firavn}

Bir dem gelür Mûsâ olur yüz bin münâcâtlar kılur

Bir dem girer kibr evine Firavn'lla Hâmân olur (49/11)

mescid:deyr (manastır, kilise)

Bir dem varur mescidlere yüzin sürer anda yire

Bir dem varur deyre girer İncîl okur ruhbân olur (49/10)

gedâ(yoksul):hakân

Bir dem görür olmış gedâ yalın tene geymiş abâ

Bir dem ganî himmet ile Fagfûr u hem Hakân olur (49/7)

şâdî (sevinçli): giryân (ağlayan)

Bir dem gelür şâdî olur bir dem gelür giryân olur (49/1)

katre:ummân

Bir dem sanasın katredür bir dem taşar Ǿummân olur (49/4)

\subsection{5. biri X biri $Y$}

cennet:nar

Bu şârdan üç yol çıkar biri cennet biri nâr (69/7)

sag omuz:sol omuz

Birisi sag omzunda birisi sol omzunda (301/10)

Rahmâni'r-rahîm:Şeytâni'r-racîm

Biri Rahmâni'r-rahîm biri Şeytâni'r-racîm (86/3) 


\section{4. İkilemeler Şeklinde Karşıt Anlamlılık}

Divan'da kullanım sıklığı açısından önemli bir yere sahip olan bu gruptaki örnekler, herhangi bir yapısal tetikleyici ya da biçim birimle birlikte hareket etmeyen ikileme şeklindeki örneklerdir. Diğer dil bilgisel yapılar gibi bir dil ürünü olan ikilemeler de söz dizimsel karşıtlığın oluşumunda önemli bir yere sahiptirler.

\subsection{XY}

\section{assı:ziyân}

Dostlık ticâretinde anılmaz assı-ziyân (264/6)

\section{helâl:harâm}

Helâl harâm karışdı assı-ziyân olısar (60/5)

evvel:âhir

Evvel âhir ol kala vü men aleyhâ fân olam (201/45)

ezel:ebed

Kendüye hayrân eylemiş ezel ebed dost bunları (415/1)

\section{irte:gice}

Irte gice ol dost1la bâzâr iden gelsün berü (287/8)

yaz:kış

Sözüm degül yaz kış içün geldi maşûka iş içün (312/7)

dün:gün

Bir niçeler turmışlar dün-gün nevbet önerler (313/7)

\section{sual:cevap}

Su'âl cevâb kelecisi buna degindür (19/8)

\section{irkek:dişi}

Irkek dişi uryân ola (272/5)

\section{benlik:senlik}

Bu benlik senlik şârını terkini uram yüriyem (213/5)

\section{yaş:kurı}

Kandayısa yaş kurı hîç sensüz olmaz biri (147/5)

\section{varlık:yokluk}

Havf ü recâ nice gelür varlık yokluk bıragana (17/7)

eyü:yavuz

Bu cümlesi eÿ̈ yavuz kamusın andan tutaram (180/3)

\section{içüm:taşum}

Mahşer güni içüm taşum nâr olursa n'ideyin ben (274/2)

\section{canlu:cansuz}

Dünyede cânlu cânsuz olımayalar sensüz (147/8)

\section{dünyâ:âhiret}


Dost ışka ulaşalıdan dünyâ âhiret bir oldı (7/8)

acı:tatlu

Bir çeşmeden akan su acı tatlu olmaya (171/6)

yir:gök

Evvel kadîmden geldüm yir gök yaradılmazdan (233/1)

\section{Sonuc}

1. Dilsel anlam ilişkilerinden biri olan karşıt anlamlılık, duygu ve düşüncelerin aktarımında hem günlük dilde hem de edebi söylemlerde sıkça başvurulan bir ifade tarzıdır. Eski Anadolu Türkçesi döneminin önemli isimlerinden biri olan Yunus Emre de şiirlerinde tasavvufi düşüncenin ifadesinde karşıt anlamlı sözcükleri ustalıkla kullanmıştır.

Bu çalışmada, Yunus Emre Divanı'nda geçen 92 adet karşıt anlamlı sözcük tespit edilerek bunların söz dizimsel birliktelikleri görülmeye çalışılmıştır. Söz konusu yapıların, sözcükler arasındaki karşıt anlamlılığı daha belirgin hale getirdiği gözlemlenmiştir. Divan’da geçen ve söz dizimsel bir yapı içerisinde yer alan şu karşıt anlamlı çiftlere ulaşılmıştır: acı:tatlu, agu:bal, âhir:ebed, âkil:dîvâne, arş:ferş, âsî:mutî, assı:ziyân, âşık:ma'şûk, âşikâre:nihân, ata:ana, âzâd ol-:mahbûs ol-, zindândan çık-:zindân ol-, bâkî:fânî, bâtın:zâhir, bay:yoksul/yohsul:bay, senlik:benlik/benlik:senlik, bugün:yarın, canlu:cansuz, cennet:nar, derd:dermân, deryâ:katre, diken:gül, dost:düşmân, duzah:cennet, dün:gün, dünyâ:âhiret, erkek:dişi, esrük:ayık, evvel:âhir, eyü:yavuz, ezel:ebed, gedâ(yoksul):hakân, gelen:giden, gice:gündüz, görinen:gören, gül-:agla-, hâs:âm, hayr:şer, müsülmân ol-:kâfir ol-, uryân yüri-:libâs gey-, hayr:şer, helâl:harâm, ışk düz-:ışk boz-, içüm:taşum, in-:çık-, irkek:dişi, irte:gice, kâfir:müselmân, ag:kara, karga:bülbül, katre:ummân, kıyam:rükû/secde, kul:sultân, küfr:îmân, Leylî:Mecnûn, mescid:deyr (manastır, kilise), Musa:Firavn, mutî ol-:âsî ol-, od:su, ogul:kız, öldüren:dirgüren, ölü:diri, pîr (yaşlı):cüvân (genç), puta hâça tap-:dîn ü imân tut-, Rahmâni'r-rahîm:Şeytâni'r-racîm, sag omuz:sol omuz, sag:sol, sual:cevap, sûd(fayda):ziyân, şâd:gam, şâdî(sevinçli):giryân(ağlayan), şark:garb, uçmag:tamu, ulu:kiçi, ulvi:süfli, uslu:delü, var:yok, varlık:yokluk, vir-:al-, viren:alan, yalan:gerçek, yaş:kurı, yaz:kış, yazug:müzd, yiğit:koca, câhil:ârifün, dün:bugün, yir:gök, zâhir:pinhân, zeber (üst):zîr (alt).

Karşıt anlamlı çiftlerden bazıları, gice vü gündüz, gice ile gündüz; yir ü gök, ne yirde ne gökde, yir ile gök... örneklerinde de görüldügü gibi farklı yapılar içerisinde yer alabilmektedir.

2. Divan'dan elde edilen karşıı anlamlı çiftler, eşgüdümlü karşıt anlamlılık, olumsuzlanan karşıt anlamlılık, seçenekli/nöbetleşe karşıt anlamlılık ve ikilemeler şeklinde karşıt anlamııık şeklinde sınıflandırılmıştır. İlk ikisi Jones'un (2002) sınıflandırmasında yer alan başlıklardan olup "seçenekli/nöbetleşe karşıt anlamlılık" tarafımızdan adlandırılmıştır. Oluşum şekilleri içerisinde karşıt anlamlı sözcükleri de barındıran ikilemeler, sözdizimsel karştllğa hizmet eden önemli yapılarından biridir. $\mathrm{Bu}$ nedenle ayrı bir başlık şeklinde sınıflandırmaya dâhil edilmiştir. Bu başlıklar altında sınıflandırılan karşıt anlamlı çiftler, söz dizimsel olarak farklı yapılar içerisinde yer almaktadırlar. Bu yapıların kuruluşu aşağıda verilmiştir:

eşgüdümlü karşıt anlamlılık: $X$ u $Y$ / $X$ vü $Y$, hem $X$ hem $Y$, ne $X$ ne $Y$, ger $X$ ger $Y$ / eger X eger Y, X ile / $\{+(\mathrm{y}) I l A\}$ Y, X oldur Y ol / oldur X oldur Y / X ol Y ol, ya X ya Y

olumsuzlanan karşıt anlamlılık: $\mathrm{X}$ degül $\mathrm{Y}\{+\mathrm{DU}\}$ / X $\{+\mathrm{DU}\}\} \mathrm{Y}$ degül, X olma Y ol, $\mathrm{X}$ yok $\mathrm{Y}\{+\mathrm{DAdur}\}$ 
seçenekli/nöbetleşe karşıt anlamlılık: gâh X gâh/geh $Y$, bir niçeleri X bir niçeleri $\mathrm{Y}$ / bir niçemüz, X ... bir niçemüz Y ..., kimi X kimi Y / kimin X ... kimin Y, bir dem X bir dem Y, biri $\mathrm{X}$ biri $\mathrm{Y}$

\section{ikilemeler şeklinde karşıt anlamlılık: XY}

3. Sözdizimsel yapılar içerisinde en yoğun kullanım eşgüdümlü karşıt anlamlılı̆ı oluşturan X u Y / X vü Y, ne X ne Y, X ile / $\{+(\mathrm{y}) I l A\}$ Y ve ikileme şeklindeki XY yapisında görülmektedir. Tüm yapılar değerlendirildiğinde "vü, hem...hem, ne...ne, ger...ger, eger...eger, ile, ya...ya, gâh...gâh, kimi...kimi", karşılaştırma bağlaçları ile "degül" olumsuzlama edatının karşıt anlamlı çiftlerin söz dizimsel birlikteliklerinde daha işlevsel oldukları görülmektedir.

4. Sözcükler arasında kavramsal düzlemde gerçekleşen karşıt anlamlılık, söz dizimsel açıdan da ele alınması gereken dilsel bir özellik taşımaktadır. Bu bakımdan söz dizimsel açıdan yapılacak analiz ve sınıflandırmalar, özellikle karş̧ı anlamlılıkla ilgili metin ya da söylem temelli araştırmalarda, yapı-anlam ilişkisinin de daha net görülmesini sağlayacaktır.

\section{Makalede Kullanılan İşaretler}

... Karşıt sözcükle aynı öbek içinde bulunan unsur.

: $\quad$ Karşıtlık ifadesi bildirir.

I veya

$+\quad$ Öncesinde isim türünde sözcük olduğunu gösterir.

- $\quad$ Öncesinde fiil türünde sözcük olduğunu gösterir.

\{ \} Biçim birimleri gösterir.

X, Y Karşıt anlamlı sözcükler.

\section{Kaynakça}

Akçataş, A. (2011). A study on antonymous relations in turkey turkish proverbs and idioms. Turkish Studies, 6/1, 311-322.

Aksan, D. (2016). Anlambilim. Ankara: Bilgi Yayınevi.

Akşehirli, S. (2014). Yapısal karşıttlk tetikleyicileri ve söylemsel karşıtlıklar. 28.Ulusal Dilbilim Kurultay1, Sakarya Üniversitesi, 8-9 Mayıs, Sakarya.

Akşehirli, S. (2018). Türkçede bağımlı karşıt anlamlılık. Dil Eğitimi ve Araştırmaları Dergisi, 4(1), 41-60.

Cruse, D. A. (2000). Meaning in Language, An Introduction to Semantics and Prgamatics. New York: Oxford University Press.

Hatiboğlu, V. (1978). Dilbilgisi terimleri sözlüğ̈̈̈. Ankara: Ankara Üniversitesi Yayınları.

İmer, K., Kocaman, A. ve Özsoy, S. (2011). Dilbilim sözlüğü. İstanbul: Boğaziçi Üniversitesi Yayınevi.

Jones, S. (2002). Antonymy: A Corpus-based Aprroach. London: Routledge.

Karaağaç, G. (2013). Anlam, anlam bilimi ve iletişim. İstanbul: Kesit Yayınları.

Kerimoğlu, C. (2014). Genel dilbilime giriş. Ankara: Pegem Akdemi.

Kıran, Z. ve Eziler Kıran, A. (2002). Dilbilime giriş. Ankara: Seçkin Yayıncılık.

Korkmaz, Z. (2007). Gramer terimleri sözlüğ̈̈. Ankara: TDK.

Korkmaz, Z. (2009). Türkiye türkçesi grameri şekil bilgisi. Ankara: TDK. 
Köprülü, M. F. (2020). Türk edebiyatında ilk mutasavvıflar. İstanbul: Alfa Basım Yayım.

Palmer, F. R. (2001). Semantik yeni bir anlam projesi (R. Ertürk, çev.). Ankara: Kitabiyat Yayınları.

Tatçı M. (2008). Yunus Emre Divanı, tenkitli metin 2. İstanbul: H Yayınları.

Tezcan, S. (2012). Eski Anadolu Türkçesi ve Yunus Emre şiirlerinin dili üzerine. A. Y. Ocak (Ed.), Yunus Emre içinde (ss. 97-123). Ankara: Kültür ve Turizm Bakanlığı.

Vardar, B. (2002). Açıklamalı dilbilim terimleri sözlüğü. İstanbul: Multilingual.

ETIKK ve BILIIMSEL İLKELER SORUMLULUK BEYANI

$\mathrm{Bu}$ çalışmanın tüm hazırlanma süreçlerinde etik kurallara ve bilimsel atıf gösterme ilkelerine riayet edildiğini yazar(lar) beyan eder. Aksi bir durumun tespiti halinde Afyon Kocatepe Üniversitesi Sosyal Bilimler Dergisi'nin hiçbir sorumluluğu olmayıp, tüm sorumluluk makale yazarlarına aittir.

\section{ARAŞTIRMACILARIN MAKALEYE KATKI ORANI BEYANI}

1. yazar katkı oranı : \% 100 